\section{Intimate partner violence among undergraduate students of two universities of the state of São Paulo, Brazil}

\section{Violência por parceiro íntimo entre estudantes de duas universidades do Estado de São Paulo, Brasil}

Tânia Aldrighi Flake', "I

Claudia Barros ${ }^{\mathrm{III}, \mathrm{IV}}$

Lilia B. Schraiber"l, III

Paulo Rossi Menezes"I, III

'Universidade Mackenzie - São Paulo (SP), Brazil.

"Postgraduate Program in Preventive Medicine at the Medical School of Universidade de São Paulo - São Paulo (SP), Brazil.

I'Departament of Preventive Medicine at the Medical School of Universidade de São Paulo - São Paulo (SP), Brazil.

IvPostgraduate Program in Public Health at the Public Health School of Universidade de São Paulo - São Paulo (SP), Brazil.

Corresponding author:Tânia Aldrighi Flake. Faculdade de Medicina da Universidade de São Paulo. Avenida Doutor Arnaldo, $4552^{\circ}$ andar, sala 2170, CEP: 01246-903, Paulo, SP, Brasil.

E-mail: siberi01@uol.com.br

Conflict of interests: nothing to declare.

\section{Abstract}

Introduction: The prevalence of violence in intimate relationships, suffered or perpetrated, was estimated among undergraduate students, be it physical, psychological and sexual, describing the overlap between them. This is an original study and there is scarce literature on this matter in Brazil. Men and women were investigated and some issues on gender violence were discussed. Methods: The study is part of the multicenter survey "International Study of Violence in Dating IDVS" conducted in 2002 - 2003, using its standardized instrument. A total of 362 students, from two universities in the state of São Paulo, one public and one private, answered the self-reported questionnaire, being $37 \%$ male and $63 \%$ female, mean age of 20 years old. Suffered and perpetrated intimate partner violence during life was examined. Results: Among all interviewees, $75.9 \%$ suffered and $76.4 \%$ perpetrated some kind of violence throughout life. Psychological violence was the most prevalent type, followed by sexual violence, both suffered and perpetrated. The great superposition between suffered and perpetrated violence (83.9\%) reflects the reciprocity of aggression, with no observed difference between men and women. The results of this study are consistent with previous literature on dating violence, which shows high prevalence of suffered and perpetrated violence, besides reciprocity for both men and women. Conclusions: Intervention actions at this stage of intimate relationships may potentially impact on subsequent marital partnership situations.

Keywords: Violence. Family violence. Spouse abuse. Interpersonal relations. Gender and health. Courtship. 


\section{Resumo}

Introdução: Foram estimados entre universitários a prevalência da violência em relacionamentos íntimos, sofrida ou perpetrada, para os tipos físico, psicológico e sexual, descrevendo-se as sobreposições entre eles. Estudo original com rara produção no Brasil. Foram pesquisados homens e mulheres, com discussão de algumas questões da violência de gênero. Método: $\mathrm{O}$ estudo faz parte de pesquisa multicêntrica "Estudo Internacional de Violência no Namoro - IDVS", realizada em 2002-2003, usando seu instrumento padronizado. O questionário foi autoaplicado em 362 alunos de duas universidades, uma pública $\mathrm{e}$ outra privada, do Estado de São Paulo, sendo $37 \%$ do sexo masculino e $63 \%$ do feminino, com idade mediana de 20 anos. Foram descritas as violências sofridas por e perpetradas na vida contra parceiros íntimos. Resultados e Discussão: Entre todos os entrevistados, 75,9\% sofreram e $76,4 \%$ perpetraram algum tipo de violência na vida. $\mathrm{O}$ tipo de violência mais prevalente, tanto sofrida como perpetrada, foi a psicológica, seguida da sexual. A grande sobreposição entre violências sofridas e perpetradas $(83,9 \%)$ reflete a reciprocidade das agressões, sem diferença entre homens e mulheres. Os resultados do presente estudo estão em consonância com a literatura que analisa a violência no namoro, com alta prevalência de violências sofridas e perpetradas, além da reciprocidade tanto para homens como para mulheres. Conclusões: Ações de intervenção nesta fase dos relacionamentos íntimos podem potencialmente repercutir em situações posteriores de parceria conjugal.

Palavras-chave: Violência. Violência doméstica. Maus-tratos conjugais. Relações interpessoais. Gênero e saúde. Corte.

\section{Introduction}

Violence between intimate partners is a public health issue, with negative implications for the physical and mental health of the men and women involved. It can be present in the dating phase, with partners living together or in a constituted marriage ${ }^{1,2}$. Many authors indicate that this violence begins at the dating phase, and it can determine the pattern of the relationship throughout its vital cycle, besides being a precursor of more serious aggressions after the transition to living together or getting married ${ }^{3-5}$. Literature review shows that, firstly, studies have been focusing on marital violence, and only after the 1980s they started focusing on dating or courtship violence ${ }^{6}$. Some studies approach it in school, pointing out that 15 to $43 \%$ of the adolescents who experienced some type of violence in a romantic relationship refer to it in the school space, be it as a personal statement or in the testimonial of others ${ }^{7}$. Despite the already revealed high rates, the high risk of violence between intimate partners in the dating phase is not entirely recognized. In Brazil, studies are still incipient ${ }^{8,9}$.

After participating in the International Dating Violence Study (IDVS), which includes the present sample of university students from São Paulo, Aldrighi describes the violent events that took place in the last 12 months, in relation to the application of the questionnaire, considering current or continuous violence. The same sample will be target of other analyses in this article, not limited to the violence that took place in the past 12 months.

If we consider that the dating phase is the time when intimate partnerships are built and when future marital relationships can be consolidated, knowing how this phenomenon can be present in this stage of human relations is extremely important and urgent. Dating can be a determining situation to prevent intimate partner violence also for marriage.

Besides the perspective to understand the constitution of an intimate relationship, the aspects associated with the process of 
developing romantic relationships, the beginning of sexual activities and the present gender issues, knowing more about the dating phenomenon also expressively contributes with the study of violence in this stage of the vital cycle. This is because the dating phase, until the mid- $20^{\text {th }}$ century, practically did not exist and was considered as a transition period to marriage. Currently, besides corresponding to a more elastic period for the constitution of intimate relationships, the dating period is comprised of several kinds of relationship, from the short and not committed ones to the point of living together ${ }^{11}$.

Gelles and Straus have stated since the 1980 s that data on intimate partner violence reflected the need to search for subsidies to understand the gender relationship from the dating phase, once the occurrence of the phenomenon in this stage broke the conception that marriage was a license for violence ${ }^{3}$.

Based on this scenario, this article aimed at: (1) describing the prevalence of perpetration and victimization of different types of violence, specifically physical, psychological and sexual, throughout life; (2) describing the superposition of the three types of violence, be the suffered or the perpetrated ones; (3) examining the prevalence and the superposition found from the male and female perspectives.

\section{Method}

It is a cross-sectional epidemiological study, in a multicenter international research (IDBS) about violence during the dating period, which included Brazil and 32 other countries. Data collection was conducted in 2002 - 2003 in the State of São Paulo ${ }^{4,10,12}$. The sample was calculated for comparison between countries with international cooperation and in a compatible manner with local studies ${ }^{4,10,19}$. It was composed of undergraduate students of two universities in the State of São Paulo - a private one, in the capital, and a public one, in Vale do Paraíba. They were chosen by the convenience of the field research since the main researcher belongs to one of them, and the existence of previous collaborations with the other institution. Students were enrolled in the courses of business administration, international trade, physical education, journalism, medicine and psychology, in order to search for more balance in the presence of men and women in the sample. At first, 510 students were in the classrooms, where they were invited to participate in the study by means of a self-reported questionnaire. There was a valid total of 456 respondents, by adding the two universities, with a $10 \%$ loss - concerning people who delivered a blank questionnaire.

Three hundred and sixty two college students were eligible for the current study; they were currently dating or had dated for at least one month. Out of these, $29.8 \%(n=108)$ did not answer the questions concerning suffered or perpetrated violence.

The questionnaire was developed, pretested, revised and used in studies about intimate partner violence with more than 10 thousand students in several regions of the worlds and consists of four parts: Social characterization, conflict tactics scale 2 (CTS2), personality and relationship profile (PRP) and the section corresponding to the relevant variables for each nation participating in the study.

The instrument was translated to Portuguese and back-translated by three Psychology professionals, who were experts on the subject - two Portuguese and one Brazilian - and back-translated to English by an expert who was fluent in the language. The comprehension and semantic content test was conducted by a small sample of university students who knew both languages, both in Portugal $(\mathrm{n}=8)$ and in Brazil $(n=5)$. The first translation was conducted separately by the countries and, afterwards, it was compared to the Portuguese version. The main divergences and critical points of the adaptation between both versions were discussed, and the final version was a result of a version with semantic equivalence to the original one, adapted and composed of questions that interest the Brazilian cultural reality. For the adaptation of the instrument, 
some procedures were defined by the leader researcher in order to guarantee conceptual equivalence. The terms were discussed and carefully reviewed by the researcher, being shared with the whole group of researchers, in order to facilitate a standardized measurement in all of the locations and ensure the benefits to investigate cultural differences. Before beginning the adaptation of the instrument, each researcher was in charge of developing a qualitative study with the objective of adapting the terminology "dating" according to the language used by young people in each participating country. In this study, dating was defined as the relationship between pairs involving one date for social interaction and activities as a couple with the explicit and/or implicit intention to maintain a romantic and intimate relationship until one of the parts end it, or until the commitment is established with an engagement, marriage or cohabitation $^{12}$. The questionnaire, by Straus, coauthor of the known Conflict Tactic Scales (CTS-1 and CTS-2)12, was very similar to these scales, but it was rearranged in a specific model for the dating phase, constituting the IDV Questionnaire.

Unlike Aldrighi ${ }^{10}$, in this study the considered violence was the one that took place during the investigated situation of intimate partnership or dating beyond the last 12 months. Each type of violence was approached by separate questions and with items that listed concrete acts that were suffered or perpetrated (Table 3). Physical violence was analyzed according to the severity of the caused damage, with the possibilities of "moderate" and "severe".

In the statistical analysis, the software STATA 10.0 was used. The variables were described by frequencies and proportions. Suffered and perpetrated violence were presented in five different ways, with the objective of giving detailed description of the violent events. At first, the prevalence of each type of violence was presented regardless of the response given to the other types, therefore, regardless of possible overlapping. Afterwards, the exclusive and combined forms of violence were presented in categories: "none,, "exclusively psychological”, "combined psychological", "physical and/or sexual" and "all of them simultaneously". Then, the proportions of superposition of any type of violence, suffered or perpetrated, were analyzed in the categories: "only suffered", "only perpetrated" and "suffered and perpetrated". All kinds of suffered and perpetrated violence were described with the questions used for each type. At last, the proportions of the superposition between the psychological, physical and sexual types were analyzed, with relation to suffered and perpetrated violence. All of the analyses were followed by the $\chi^{2}$ and Pearson's tests to compare between genders. For some variables with order, the tendency test was used. A 5\% significance level was adopted.

In the loss corrections of violence questions, the method of multiple data imputation was used. The variables selected for probabilistic imputation were: "sexual relationship with partner", associated with violence, and "sex", since literature points out it is associated with suffered and perpetrated violence in marital relationships ${ }^{13}$. The research was approved by the Research Ethics Committee of the institution that based it. Among the ethical care, there are some items: the signature of the post-informed consent form, anonymity and confidentiality of responses, and information given to the participants, printed out as the cover of the questionnaire. With respect to privacy and the voluntary nature of participation, instructions emphasized that respondents were free to participate and could omit any question they did not wish to answer. Also, services addressed to psychological and/or specialized care to treat people experiencing violent situations were publicized, as well as the e-mail and the telephone number of the research coordinator.

\section{Results}

Out of the final sample of 362 participants, $132(37 \%)$ were male and 228 (63\%) were female. Most of them studied in the private university and attended the two fist years of the respective course, corresponding 
to $70 \%$ of the sample. Women were mostly present in the first two years of graduation $\left(\left(\mathrm{p}_{\text {tend }}<0.001\right)\right.$ (Table 1$)$. The age of the participants ranged from 18 to 39 years old, with mean age of 20 years old and $69.4 \%$ between 18 and 21 years old. The female gender corresponded to the youngest population when compared to the male gender, with $\mathrm{p}_{\text {tend }}<$ 0.001 (Table 1). With regard to family income, $62 \%$ of the families were in the three first income rates, with no difference between the genders of the respondents (Table 1). Still, in Table 1, concerning the intimate relationship, it was observed that more than half of the sample referred the current relationship lasting for more than one month (61.0\%), being $55.2 \%$ for men and $64.5 \%$ for women, while $39.0 \%$ referred to have had a previous relationship that lasted at least one month. Most of them (91.0\%) reported not living with a partner and being homossexuals; $71.2 \%$ reported that sexual life was part of the relationship. Considering that $9 \%$ of the sample lived with a partner and that the study was designed to discuss violence during dating, it was tested if this category could lead to differences in the results as to magnitude and types of violence. Since there was no difference for men or for women, the sample was considered as a whole in the dialogue with literature about violence in dating. Finally, in relation to the characteristics of the parents, it was observed that the most frequent schooling was the higher education, and mostly for the paternal situation (55.3\%), but nor for the mothers (44.4\%). Concerning marital status, most (71.5\%) was married (Table 1).

In Table 2, high prevalence (76\%) of suffered and/or perpetrated violence was observed, especially psychological violence, followed by sexual violence, regardless of any superposition or combination. However, after the stratification of the types of suffered and perpetrated violence and considering exclusive and combined types, the most prevalent one among the suffered types of violence was not the psychological one, but its combined forms (41.5\% - 150 cases), as well as in perpetrated violence ( $40.1 \%$ - 145 cases).
There were no statistically significant differences as to the types of violence between men and women (Table 2). After analyzing any type of suffered and perpetrated violence according to the duration of the relationship, an increasing tendency of the episodes of violence (both suffered and perpetrated) was observed with the longer duration of relationships, in both genders ( $\left.\mathrm{p}_{\text {tend }}<0.001\right)$. It was also observed that $84 \%$ of the college students reported suffering and perpetrating violence against his or her partners, regardless of gender (Table 2).

Table 3 describes in detail each type of suffered and perpetrated violence. Similar patterns were found for both types of violence, regardless of gender. Among them, the most prevalent was the psychological one, followed by sexual and physical moderate violence; severe physical violence was the least prevalent one.

Out of the total number of suffered violence (Figure 1), it was observed that among the exclusive forms, proportions were: $33.6 \%$, psychological; $8.4 \%$, sexual; and $1.5 \%$, physical. Considering the superposition of types of violence, the greatest magnitude corresponds to the combination of psychological and sexual violence, followed by three simultaneous types. No statistically significant differences were observed between men and women.

In relation to the types of perpetrated violence, proportions presented similar distribution to the suffered violence: in exclusive types, $39.1 \%$, psychological; $4.7 \%$, sexual; and $2.9 \%$, physical. In the superposition of these occurrences, the same pattern was verified. There were no statistically significant differences between men and women (Figure 2).

\section{Discussion}

In literature, there is great diversity of studies with different conceptions of violence reflected on the used instruments and also with different definitions of the sample and methodological analysis strategies. In the comparison with international studies 
Table 1 - Total and stratified frequencies and proportions by sex and sociodemographic characteristics in the relationship. São Paulo. 2002.

Tabela 1 - Frequências e proporções total e estratificada por sexo das características sociodemográficas e relativas ao relacionamento. São Paulo. 2002.

\begin{tabular}{|c|c|c|c|c|c|c|}
\hline \multirow{3}{*}{ Variable } & \multirow{2}{*}{\multicolumn{2}{|c|}{ Total }} & \multicolumn{4}{|c|}{ Gender } \\
\hline & & & \multicolumn{2}{|c|}{ Men } & \multicolumn{2}{|c|}{ Women } \\
\hline & $\mathrm{n}$ & $\%$ & $\mathrm{n}$ & $\%$ & $\mathrm{n}$ & $\%$ \\
\hline \multicolumn{7}{|l|}{ College $(n=362)$} \\
\hline Private university & 197 & 54.4 & 68 & 50.8 & 129 & 56.6 \\
\hline Public university & 165 & 45.6 & 66 & 49.2 & 99 & 44.4 \\
\hline $\mathrm{p}$-value & & & & & & 0.282 \\
\hline \multicolumn{7}{|l|}{ Years in university $(n=359)$} \\
\hline Freshman & 210 & 58.5 & 56 & 42.1 & 154 & 68.1 \\
\hline $2^{\text {nd }}$ years & 70 & 19.5 & 30 & 22.6 & 40 & 17.7 \\
\hline $3^{\text {rd }}$ year & 76 & 21.2 & 45 & 33.8 & 31 & 13.7 \\
\hline $4^{\text {th }}$ year & 3 & 0.8 & 2 & 1.5 & 1 & 0.5 \\
\hline p-value & & & & & & $<0.001$ \\
\hline \multicolumn{7}{|l|}{ Age $(n=360)$} \\
\hline 18 & 68 & 18.9 & 12 & 9.1 & 56 & 24.6 \\
\hline 19 & 70 & 19.4 & 15 & 11.4 & 55 & 24.1 \\
\hline 20 & 68 & 18.9 & 28 & 21.2 & 40 & 17.5 \\
\hline 21 & 44 & 12.2 & 19 & 14.4 & 25 & 11.0 \\
\hline $22-24$ & 57 & 15.8 & 25 & 18.9 & 32 & 14.0 \\
\hline $25-29$ & 32 & 8.9 & 22 & 16.7 & 10 & 4.4 \\
\hline $30-39$ & 21 & 5.9 & 11 & 8.3 & 10 & 4.4 \\
\hline p-value & & & & & & $<0.001$ \\
\hline \multicolumn{7}{|l|}{ Family income $(n=350)$} \\
\hline Less than $\mathrm{R} \$ 10,000$ & 89 & 25.4 & 24 & 18.2 & 65 & 29.8 \\
\hline $\mathrm{R} \$ 10,000$ to 19,999 & 86 & 24.6 & 30 & 22.7 & 56 & 25.7 \\
\hline $\mathrm{R} \$ 20,000$ to 29.999 & 42 & 12.0 & 15 & 11.4 & 27 & 12.4 \\
\hline $\mathrm{R} \$ 30,000$ to 39,999 & 37 & 10.6 & 17 & 12.9 & 20 & 9.2 \\
\hline $\mathrm{R} \$ 40,000$ to 49,999 & 24 & 6.9 & 11 & 8.3 & 13 & 6.0 \\
\hline $\mathrm{R} \$ 50,000$ to 59,999 & 14 & 4.0 & 6 & 4.5 & 8 & 3.7 \\
\hline $\mathrm{R} \$ 60,000$ to 69,999 & 13 & 3.7 & 6 & 4.5 & 7 & 3.2 \\
\hline More than $\mathrm{R} \$ 70,000$ & 45 & 12.8 & 23 & 17.5 & 22 & 10.0 \\
\hline $\mathrm{p}$-value & & & & & & 0.148 \\
\hline \multicolumn{7}{|l|}{ Dating situation $(\mathrm{n}=362)$} \\
\hline One month or more & 221 & 61.0 & 74 & 55.2 & 147 & 64.5 \\
\hline Previous & 141 & 39.0 & 60 & 44.8 & 81 & 35.5 \\
\hline$p$-value & & & & & & 0.081 \\
\hline \multicolumn{7}{|l|}{ Type of relationship/cohabitation $(n=356)$} \\
\hline Boyfriend-girlfriend/living with partner & 2 & 0.6 & 1 & 0.8 & 1 & 0.4 \\
\hline $\begin{array}{l}\text { Boyfriend-girlfriend/not living with } \\
\text { partner }\end{array}$ & 58 & 16.3 & 26 & 19.7 & 32 & 14.3 \\
\hline Engaged/living with partner & 13 & 3.6 & 9 & 6.8 & 4 & 1.8 \\
\hline Engaged/ not living with partner & 266 & 74.7 & 92 & 69.7 & 174 & 77.7 \\
\hline Married/ living with partner & 15 & 4.2 & 4 & 3.0 & 11 & 4.9 \\
\hline $\begin{array}{l}\text { Married / not living with partner } \\
\text { p-value }\end{array}$ & 2 & 0.6 & 0 & 0 & 2 & 0.9 \\
\hline
\end{tabular}


Tabela 1 - Continuação.

Table 1 - Continuation.

\begin{tabular}{|c|c|c|c|c|c|c|}
\hline \multirow{3}{*}{ Variable } & \multirow{2}{*}{\multicolumn{2}{|c|}{ Total }} & \multicolumn{4}{|c|}{ Gender } \\
\hline & & & \multicolumn{2}{|c|}{ Men } & \multicolumn{2}{|c|}{ Women } \\
\hline & $\mathrm{n}$ & $\%$ & $\mathrm{n}$ & $\%$ & $\mathrm{n}$ & $\%$ \\
\hline \multicolumn{7}{|l|}{ End of relationship $(n=355)$} \\
\hline Did not end & 217 & 61.2 & 72 & 55.0 & 145 & 64.7 \\
\hline$<1$ month & 21 & 5.9 & 6 & 4.6 & 15 & 6.7 \\
\hline 1 month & 13 & 3.7 & 6 & 4.6 & 7 & 3.2 \\
\hline 2 months ago & 14 & 3.9 & 8 & 6.1 & 6 & 2.7 \\
\hline 3 to 5 months & 25 & 7.0 & 14 & 10.7 & 11 & 4.9 \\
\hline 6 to 11 months & 14 & 3.9 & 5 & 3.8 & 9 & 4.0 \\
\hline 1 year & 15 & 4.2 & 4 & 3.0 & 11 & 4.9 \\
\hline$>1$ year & 36 & 10.2 & 16 & 12.2 & 20 & 8.9 \\
\hline $\mathrm{p}$-value & & & & & & 0.172 \\
\hline \multicolumn{7}{|l|}{ Partner's gender $(n=361)$} \\
\hline Homossexual relationship & 9 & 2.5 & 5 & 3.8 & 4 & 1.8 \\
\hline Heterossexual relationship & 352 & 97.5 & 128 & 96.2 & 224 & 98.2 \\
\hline p-value & & & & & & 0.299 \\
\hline \multicolumn{7}{|l|}{ Sexual life $(n=361)$} \\
\hline No & 104 & 28.8 & 36 & 27.1 & 68 & 29.8 \\
\hline Yes & 257 & 71.2 & 97 & 72.9 & 160 & 70.2 \\
\hline p-value & & & & & & 0.577 \\
\hline \multicolumn{7}{|l|}{ Schooling of the father $(n=360)$} \\
\hline Elementary School & 67 & 18.6 & 29 & 21.8 & 38 & 16.7 \\
\hline Incomplete high school & 36 & 10.0 & 14 & 10.5 & 22 & 9.7 \\
\hline Complete high school & 58 & 16.1 & 19 & 14.3 & 39 & 17.2 \\
\hline Incomplete graduation & 50 & 13.9 & 16 & 12.0 & 34 & 15.0 \\
\hline Complete graduation & 113 & 31.4 & 40 & 30.1 & 73 & 32.2 \\
\hline Postgraduation & 36 & 10.0 & 15 & 11.3 & 21 & 9.2 \\
\hline p-value & & & & & & 0.757 \\
\hline \multicolumn{7}{|c|}{ Schooling of the mother $(n=362)$} \\
\hline Elementary School & 67 & 18.5 & 25 & 18.7 & 42 & 18.4 \\
\hline Incomplete high school & 42 & 11.6 & 15 & 11.2 & 27 & 11.8 \\
\hline Complete high school & 96 & 26.5 & 38 & 28.4 & 58 & 25.4 \\
\hline Incomplete graduation & 31 & 8.6 & 12 & 8.9 & 19 & 8.3 \\
\hline Complete graduation & 105 & 29.0 & 36 & 26.9 & 69 & 30.3 \\
\hline Postgraduation & 21 & 5.8 & 8 & 5.9 & 13 & 5.8 \\
\hline p-value & & & & & & 0.983 \\
\hline \multicolumn{7}{|c|}{ Marital status of parents $(n=358)$} \\
\hline Married & 256 & 71.5 & 85 & 64.4 & 171 & 75.7 \\
\hline Separated & 26 & 7.3 & 11 & 8.3 & 15 & 6.6 \\
\hline Divorced & 38 & 10.6 & 20 & 15.2 & 18 & 8.0 \\
\hline Not married, not together & 7 & 2.0 & 4 & 3.0 & 3 & 1.3 \\
\hline Not married, together & 4 & 1.1 & 2 & 1.5 & 2 & 0.9 \\
\hline Dead & 27 & 7.5 & 10 & 7.6 & 17 & 7.5 \\
\hline $\mathrm{p}$-value & & & & & & 0.163 \\
\hline
\end{tabular}


Table 2 - Prevalence of experienced and perpetrated violence and frequencies and proportions of the overlap of two events (experienced and perpetrated). São Paulo. 2002.

Tabela 2 - Prevalência de violência sofrida e perpetrada e frequências e proporções da sobreposição das duas ocorrências (sofrida e perpetrada). São Paulo. 2002.

\begin{tabular}{|c|c|c|c|c|c|c|c|c|c|}
\hline \multirow{2}{*}{ Variables } & \multicolumn{3}{|c|}{ Total $(n=361)$} & \multicolumn{3}{|c|}{ Men $(n=133)$} & \multicolumn{3}{|c|}{ Women $(n=228)$} \\
\hline & $\mathrm{n}$ & $\%$ & $95 \% \mathrm{Cl}$ & $\mathrm{n}$ & $\%$ & $95 \% \mathrm{Cl}$ & $\mathrm{n}$ & $\%$ & $95 \% \mathrm{Cl}$ \\
\hline \multicolumn{10}{|c|}{ Experienced violence regardless of overlapping } \\
\hline \multicolumn{10}{|c|}{ Psychological } \\
\hline No & 119 & 33.0 & $28.1-37.8$ & 48 & 36.1 & $27.9-44.3$ & 71 & 31.1 & $25.1-37.2$ \\
\hline Yes & 242 & 67.0 & $62.2-71.9$ & 85 & 63.9 & $55.7-72.1$ & 157 & 68.9 & $62.8-74.9$ \\
\hline $\mathrm{p}$-value & & & & & & & & & 0.335 \\
\hline \multicolumn{10}{|l|}{ Physical } \\
\hline No & 269 & 74.5 & $69.9-79.0$ & 96 & 72.2 & $64.5-79.8$ & 173 & 75.9 & $70.3-81.5$ \\
\hline Yes & 92 & 25.5 & $21.0-30.0$ & 37 & 27.8 & $20.1-35.5$ & 55 & 24.1 & $18.5-29.7$ \\
\hline p-value & & & & & & & & & 0.437 \\
\hline \multicolumn{10}{|l|}{ Sexual } \\
\hline No & 220 & 60.9 & $55.9-65.9$ & 84 & 63.2 & $54.9-71.4$ & 136 & 59.6 & $53.2-66.0$ \\
\hline Yes & 141 & 39.1 & $34.0-44.0$ & 49 & 36.8 & $28.6-45.1$ & 92 & 40.4 & $33.9-46.7$ \\
\hline$p$-value & & & & & & & & & 0.510 \\
\hline \multicolumn{10}{|c|}{ Physical and/or sexual and/or psychological } \\
\hline No & 87 & 24.1 & $19.7-28.5$ & 33 & 24.8 & $17.4-32.2$ & 54 & 23.7 & $18.1-29.2$ \\
\hline Yes & 274 & 75.9 & $71.5-80.3$ & 100 & 75.2 & $67.8-82.6$ & 174 & 76.3 & $70.8-81.9$ \\
\hline p-value & & & & & & & & & 0.809 \\
\hline \multicolumn{10}{|c|}{ Combined experienced violence } \\
\hline None & 87 & 24.1 & $19.7-28.5$ & 33 & 24.8 & $17.4-32.3$ & 54 & 23.7 & $18.1-29.2$ \\
\hline Only psychological & 92 & 25.5 & $20.9-30.0$ & 36 & 27.1 & $19.4-34.7$ & 56 & 24.6 & $18.9-30.2$ \\
\hline $\begin{array}{l}\text { Psychological } \\
\text { combined }\end{array}$ & 104 & 28.8 & $24.1-33.5$ & 29 & 21.8 & $14.7-28.9$ & 75 & 32.9 & $26.7-39.0$ \\
\hline Physical and/or sexual & 32 & 8.9 & $5.9-11.8$ & 15 & 11.3 & $5.8-16.7$ & 17 & 7.5 & $4.0-10.9$ \\
\hline All simultaneously & 46 & 12.7 & $9.3-16.2$ & 20 & 15.0 & $8.9-21.2$ & 26 & 11.3 & $7.2-15.6$ \\
\hline $\mathrm{p}$-value & & & & & & & & & 0.192 \\
\hline \multicolumn{10}{|c|}{ Perpetrated violence regardless of overlapping } \\
\hline \multicolumn{10}{|c|}{ Psychological } \\
\hline No & 108 & 29.9 & $25.2-34.7$ & 41 & 30.8 & $22.9-38.7$ & 67 & 29.4 & $23.4-35.3$ \\
\hline Yes & 253 & 70.1 & $65.3-74.8$ & 92 & 69.2 & $61.3-77.1$ & 161 & 70.6 & $64.7-76.6$ \\
\hline p-value & & & & & & & & & 0.7773 \\
\hline \multicolumn{10}{|l|}{ Physical } \\
\hline No & 273 & 75.6 & $71.2-80.1$ & 101 & 75.9 & $68.6-83.2$ & 172 & 75.4 & $69.8-81.0$ \\
\hline Yes & 88 & 24.4 & $19.9-28.8$ & 32 & 24.1 & $16.7-31.3$ & 56 & 24.6 & $18.9-30.2$ \\
\hline $\mathrm{p}$-value & & & & & & & & & 0.915 \\
\hline \multicolumn{10}{|l|}{ Sexual } \\
\hline No & 237 & 65.6 & $60.7-70.6$ & 81 & 60.9 & $52.5-69.2$ & 156 & 68.4 & $30.7-47.4$ \\
\hline Yes & 124 & 34.4 & $29.4-39.3$ & 52 & 39.1 & $62.3-74.5$ & 72 & 31.6 & $25.5-37.6$ \\
\hline p-value & & & & & & & & & 0.147 \\
\hline \multicolumn{10}{|c|}{ Physical and/or sexual and/or psychological } \\
\hline No & 85 & 23.6 & $19.1-27.9$ & 28 & 21.0 & $14.1-28.0$ & 57 & 25.0 & $71.9-85.9$ \\
\hline Yes & 276 & 76.4 & $72.0-80.8$ & 105 & 79.0 & $19.3-30.6$ & 171 & 75.0 & $69.3-80.6$ \\
\hline $\mathrm{p}$-value & & & & & & & & & 0.394 \\
\hline
\end{tabular}


Table 2 - Continuation.

Tabela 2 - Continuação.

\begin{tabular}{|c|c|c|c|c|c|c|c|c|c|}
\hline \multirow{2}{*}{ Variables } & \multicolumn{3}{|c|}{ Total $(n=361)$} & \multicolumn{3}{|c|}{ Men $(n=133)$} & \multicolumn{3}{|c|}{ Women $(n=228)$} \\
\hline & $\mathrm{n}$ & $\%$ & $95 \% \mathrm{Cl}$ & $\mathrm{n}$ & $\%$ & $95 \% \mathrm{Cl}$ & $\mathrm{n}$ & $\%$ & $95 \% \mathrm{Cl}$ \\
\hline \multicolumn{10}{|c|}{ Combined perpetrated violence } \\
\hline None & 85 & 23.6 & $19.1-27.9$ & 28 & 21.0 & $14.0-28.1$ & 57 & 25.0 & $19.3-30.7$ \\
\hline Only psychological & 108 & 29.9 & $25.2-34.7$ & 38 & 28.6 & $20.8-36.3$ & 70 & 30.7 & $24.7-36.7$ \\
\hline $\begin{array}{l}\text { Psychological } \\
\text { combined }\end{array}$ & 103 & 28.5 & $23.8-33.2$ & 39 & 29.3 & $21.4-37.2$ & 64 & 28.1 & $22.2-33.9$ \\
\hline Physical and/or sexual & 23 & 6.4 & $3.8-8.9$ & 13 & 9.8 & $4.7-14.9$ & 10 & 4.4 & $1.7-7.1$ \\
\hline $\begin{array}{l}\text { All simultaneously } \\
\text { p-value }\end{array}$ & 42 & 11.6 & $8.3-14.9$ & 15 & 11.3 & $5.8-16.7$ & 27 & 11.8 & $\begin{array}{c}7.6-16.1 \\
0.333\end{array}$ \\
\hline \multicolumn{10}{|c|}{ Perpetrated and experienced overlapping } \\
\hline Only experienced & 23 & 7.7 & $19.1-27.9$ & 6 & 5.4 & $14.0-28.1$ & 17 & 9.0 & $19.3-30.7$ \\
\hline Only perpetrated & 25 & 8.4 & $25.2-34.7$ & 11 & 9.9 & $20.8-36.3$ & 14 & 7.4 & $24.7-36.7$ \\
\hline $\begin{array}{l}\text { Experienced and } \\
\text { perpetrated }\end{array}$ & 251 & 83.9 & $8.8-15.6$ & 94 & 84.7 & $5.8-16.7$ & 157 & 83.6 & $8.4-17.1$ \\
\hline $\mathrm{p}$-value & & & & & & & & & 0.424 \\
\hline
\end{tabular}

Total da amostra 361, porque tem um missing na vida sexual (variável utilizada para imputação de dados).

Total sample of 361 because there is one missing in sexual life (variable used for data imputation).

that show similar sample characteristics and data analysis with the same case definition used in this study, it is possible to observe that the rate found here $(75.9 \%)$ for the experience of some type of violence in life is very close to the highest limit $(82.0 \%)$ of variation of rates shown in literature ${ }^{14,15}$, including reciprocity of aggressions ${ }^{16,17}$. International studies participating in the same multicenter study, IDVS, in which we are located, only published the analysis for the prevalence of current violence ${ }^{4,5,18}$. The results of this study indicating that the psychological and the sexual violence are, in this order, the two highest rates, both in the "suffered" and in the "perpetrated" modalities, are similar to those presented by international studies ${ }^{19-21}$.

One of the aspects considered by some authors in the analysis of violence caused by an intimate partner is the fact that this event tends to appear from younger ages, when those involved are still in high school $^{22,23}$. When the prevalence between the group of high school teenagers and college students is compared, the variation in the rates for physical violence among high school teenagers is from 15 to $20 \%$, while for college students it is from 20 to $30 \%{ }^{24}$. In the case of psychological violence, values were between 82 and $87 \%$ for the group of college students and $95 \%$ for the ones in high school ${ }^{25}$.

A recent study of the Brazilian population with this younger segment, aged from 15 to 19 years old, in the region of Manaus ${ }^{9}$, points out that 88.7 and $89.2 \%$ of the sample referred to have suffered and perpetrated, respectively, some type of violence. It is important to emphasize that there is no explicit reference to whether the considered violence had took place in the past 12 months or not. However, despite using different methodologies, the value found for suffered $(75.9 \%)$ and perpetrated violence (76.9\%) in this study confirms the finding that magnitudes between perpetrated and suffered violence are close.

While most studies about violence during dating focus more on the factors associated with physical violence and victimization, little emphasis is given to psychological violence or its combination with physical violence. In adolescents, the concomitance between these two types of violence is expressive. International studies on the subject, such as the review by Mahoney, Williams and West state that approximately $28 \%$ of the teenagers, at some point during romantic 
Table 3 - Total and stratified frequencies and proportions by sex of questions about the suffered and perpetrated violence. Sao Paulo. 2002.

Tabela 3 - Frequências e proporções totais e estratificadas por sexo das perguntas referentes às violências sofridas e perpetradas. São Paulo. 2002.

\begin{tabular}{|c|c|c|c|c|c|c|}
\hline \multirow{3}{*}{ Variables } & \multirow{2}{*}{\multicolumn{2}{|c|}{ Total }} & \multicolumn{4}{|c|}{ Sex } \\
\hline & & & \multicolumn{2}{|c|}{ Men } & \multicolumn{2}{|c|}{ Women } \\
\hline & $\mathrm{n}$ & $\%$ & $\mathrm{n}$ & $\%$ & $\mathrm{n}$ & $\%$ \\
\hline \multicolumn{7}{|l|}{ Experienced violence } \\
\hline \multicolumn{7}{|l|}{ Moderate physical } \\
\hline \multicolumn{7}{|c|}{ Partner threw something at me that might have hurt } \\
\hline \multicolumn{7}{|c|}{ Partner twisted my arm or pulled my hair } \\
\hline \multicolumn{7}{|c|}{ Partner pushed or shook me } \\
\hline \multicolumn{7}{|c|}{ Partner grabbed me against my will } \\
\hline \multicolumn{7}{|c|}{ Partner hit me } \\
\hline Never & 280 & 77.6 & 104 & 78.2 & 176 & 77.2 \\
\hline At least once & 81 & 22.4 & 29 & 21.8 & 52 & 22.8 \\
\hline p-value & & & & & & 0.826 \\
\hline \multicolumn{7}{|l|}{ Severe physical } \\
\hline \multicolumn{7}{|c|}{ Partner used a knife or weapon against me } \\
\hline \multicolumn{7}{|c|}{ Partner punched me } \\
\hline \multicolumn{7}{|c|}{ Tried to strangle me } \\
\hline \multicolumn{7}{|c|}{ Threw me against the wall } \\
\hline \multicolumn{7}{|c|}{ Beat me } \\
\hline \multicolumn{7}{|l|}{ Burned me } \\
\hline Never & 330 & 91.4 & 118 & 88.7 & 212 & 93.0 \\
\hline At least once & 31 & 8.6 & 15 & 11.3 & 16 & 7.0 \\
\hline p-value & & & & & & 0.176 \\
\hline \multicolumn{7}{|l|}{ Psychological } \\
\hline \multicolumn{7}{|c|}{ My partner insulted me and called me names } \\
\hline \multicolumn{7}{|c|}{ Screamed or yelled at me } \\
\hline \multicolumn{7}{|c|}{ Left the room abruptly (or the house or the garden) during an argument } \\
\hline Did something $\mathrm{t}$ & tate $\mathrm{m}$ & & & & & \\
\hline Called me fat an & rrible & & & & & \\
\hline Destroyed some & g of $\mathrm{m}$ & & & & & \\
\hline Accused me of $b$ & a bac & & & & & \\
\hline Threatened to $\mathrm{h}$ & throw & thing & & & & \\
\hline Never & 119 & 33.0 & 48 & 36.1 & 71 & 31.1 \\
\hline At least once & 242 & 67.0 & 85 & 63.9 & 157 & 68.9 \\
\hline$p$-value & & & & & & 0.335 \\
\hline Sexual & & & & & & \\
\hline Made me have 4 & tecte & $n=16$ & & & & \\
\hline Insisted to have & when I & ot war & $=167)$ & & & \\
\hline Insisted to have & or ana & $h=16$ & & & & \\
\hline Used force to ha & ral or & $x(n=$ & & & & \\
\hline Used force to ha & $\operatorname{ex}(n=$ & & & & & \\
\hline Threatened me & ive ora & al sex & & & & \\
\hline Threatened me & ive sex & 67) & & & & \\
\hline Never & 220 & 60.9 & 84 & 63.2 & 136 & 59.6 \\
\hline At least once & 141 & 39.1 & 49 & 36.8 & 92 & 40.4 \\
\hline $\mathrm{p}$-value & & & & & & 0.510 \\
\hline
\end{tabular}


Table 3 - Continuation.

Tabela 3 - Continuação.

\begin{tabular}{|c|c|c|c|c|c|c|}
\hline \multirow{3}{*}{ Variables } & \multirow{2}{*}{\multicolumn{2}{|c|}{ Total }} & \multicolumn{4}{|c|}{ Sex } \\
\hline & & & \multicolumn{2}{|c|}{ Men } & \multicolumn{2}{|c|}{ Women } \\
\hline & $\mathrm{n}$ & $\%$ & $\mathrm{n}$ & $\%$ & $\mathrm{n}$ & $\%$ \\
\hline \multicolumn{7}{|l|}{ Perpetrated violence } \\
\hline \multicolumn{7}{|l|}{ Moderate physical } \\
\hline \multicolumn{7}{|c|}{ Threw something that might have hurt } \\
\hline \multicolumn{7}{|c|}{ Twisted his/her arm and puller his/her hair } \\
\hline \multicolumn{7}{|c|}{ Pushed or shook him/her } \\
\hline \multicolumn{7}{|c|}{ Grabbed my partner against his/her will } \\
\hline \multicolumn{7}{|l|}{ Hit my partner } \\
\hline Never & 276 & 76.4 & 103 & 77.4 & 173 & 75.9 \\
\hline At least once & 85 & 23.6 & 30 & 22.6 & 55 & 24.1 \\
\hline p-value & & & & & & 0.735 \\
\hline \multicolumn{7}{|l|}{ Severe physical } \\
\hline \multicolumn{7}{|c|}{ Used a knife or weapon against him/her } \\
\hline \multicolumn{7}{|c|}{ Punched him/her } \\
\hline \multicolumn{7}{|c|}{ Tried to strangle him/her } \\
\hline \multicolumn{7}{|c|}{ Threw him/her against the wall } \\
\hline \multicolumn{7}{|c|}{ Beat him/her } \\
\hline \multicolumn{7}{|l|}{ Burned him/her } \\
\hline Never & 340 & 94.2 & 125 & 94.0 & 215 & 94.3 \\
\hline At least once & 21 & 5.8 & 8 & 6.0 & 13 & 5.7 \\
\hline p-value & & & & & & 1.000 \\
\hline \multicolumn{7}{|c|}{ Psychological } \\
\hline \multicolumn{7}{|c|}{ Insulted and called him/her names } \\
\hline \multicolumn{7}{|c|}{ Screamed or yelled at him/her } \\
\hline \multicolumn{7}{|c|}{ I left the room, or the house or the garden abruptly during an argument } \\
\hline Did something tc & tate $\mathrm{h}$ & & & & & \\
\hline Called him/her fa & d hor & & & & & \\
\hline Destroyed some & g of hi & & & & & \\
\hline Accused him/her & peing & over & & & & \\
\hline Threatened to hi & throw & hing & & & & \\
\hline Never & 108 & 29,9 & 41 & 30,8 & 67 & 29.4 \\
\hline At least once & 253 & 70.1 & 92 & 69.2 & 161 & 70.6 \\
\hline p-value & & & & & & 0.812 \\
\hline Sexual & & & & & & \\
\hline Forced him/her $\mathrm{t}$ & ve un & ted se & & & & \\
\hline Insisted to have & when I & $\operatorname{did} n$ & t to & & & \\
\hline Insisted to have & or ana & & & & & \\
\hline Used force to ha & ral or a & & & & & \\
\hline Used force to ha & & & & & & \\
\hline Threatened to ha & pral or & & & & & \\
\hline Threatened to ha & & & & & & \\
\hline Never & 237 & 65.6 & 81 & 60.9 & 156 & 68.4 \\
\hline At least once & 124 & 34.4 & 52 & 39.1 & 72 & 31.6 \\
\hline p-value & & & & & & 0.147 \\
\hline
\end{tabular}




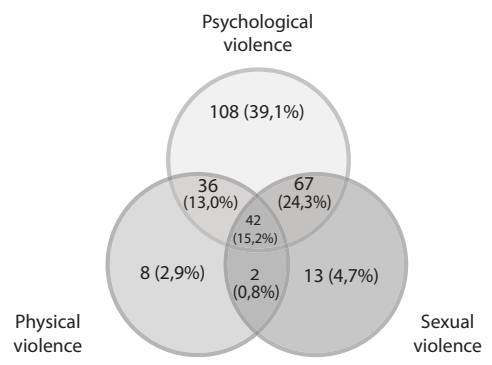

Superposition of total suffered violence $(n=276)$, without statistically significant differences between genders $(p=0.298)$

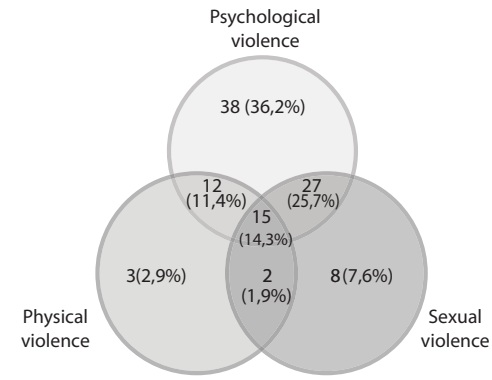

Superposition of suffered violence among men $(n=105)$

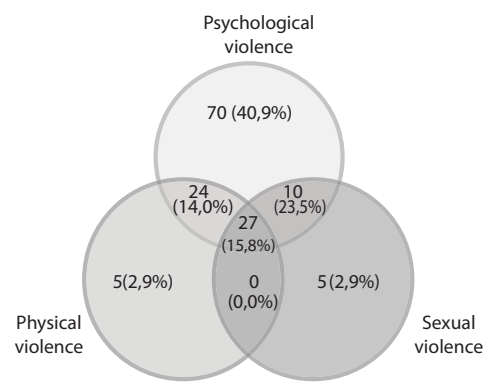

Superposition of suffered violence among women $(n=171)$

Figure 1 - Superposition of suffered violence - Overlapping types of suffered violence - 2002.

Figura 1 - Sobreposição das violências sofridas - Sobreposição dos tipos de violência sofrida - 2002.

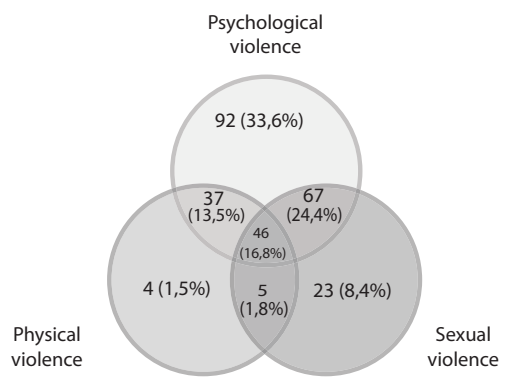

Superposition of total perpetrated violence $(n=274)$, without statistically significant differences between genders $(p=0.069)$

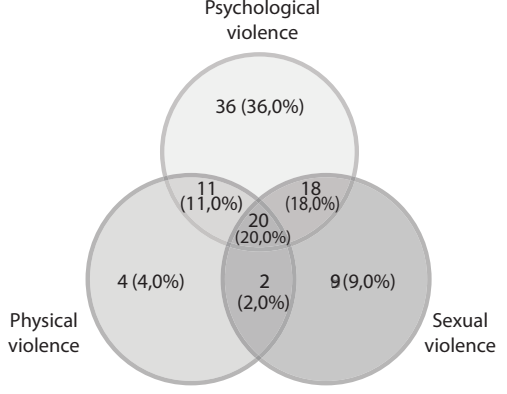

Superposition of perpetrated violence among men $(n=100)$

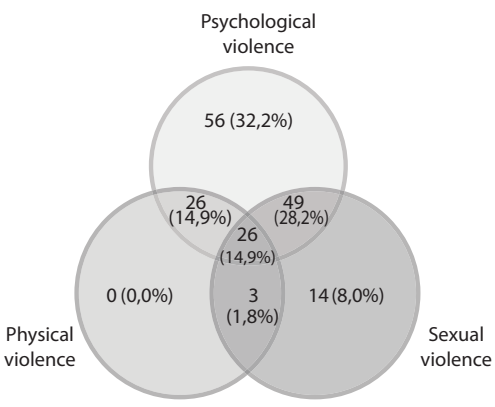

Superposition of perpetrated violence among women $(n=174)$

Figure 2 - Overlapping types of perpetrated violence.

Figura 2 - Sobreposição dos tipos de violência perpetrada. 
relationships, superposed types of violence have been present ${ }^{26}$. Even considering that this study treated the violence occurred during life, the combination of physical and psychological violence was also found here, even if at lower rates in comparison to the superposition of psychological and sexual violence. After emphasizing the importance of psychological violence, this study is in accordance with others that point it out as the precursor of physical violence in the intimate relationship during the dating phase $\mathrm{e}^{27-30}$.

Concerning sexual violence, the results found in this study present the same tendency as the ones in international studies. These show magnitudes of perpetrated sexual violence that range from 3.0 to $37.0 \%$ for man and from 2.0 to $24.0 \%$ for women. In case of suffered violence, magnitudes range from 14.0 to $43.0 \%$ for women and 0.3 to $36.0 \%$ for men $^{22,31}$. Literature comments on the higher occurrence of sexual violence affecting women in relation to men, which only is confirmed in this data base when the occurrence is examined in the past 12 months ${ }^{10}$. The reviews by Hickmanl ${ }^{22}$ and Munõz-Rivas31 point out to a reduced number of studies about sexual violence among teenagers and young adults, almost always related to the North-American reality. The authors alert to premature conclusions and the need to amplify the comprehension of this type of violence, and yet, to the superposition with the psychological type.

Another matter concerns the behavior of men and women. In this study, behaviors show no statistical difference, in accordance with others, be the ones that analyzed violence in the past 12 months, in which most refers that mutuality of aggressions ranges from 47 to $94.6 \%{ }^{4,32}$, be the ones considering the occurrence of violence in life ${ }^{16}$. Some authors indicate that both in the dating phase and in marital life there would be reciprocity of aggressions that took place in the past 12 months $^{33}$. However, others point out the methodological matters to be discussed and differences as to the type and severity of violence when men and women are compared; therefore, there is no longer symmetry in sexual violence nor in more severe cases of physical violence $e^{23,34,35}$. It is worth to notice that the more common perpetration of men than women in sexual violence is an immutable result for studies that consider the past 12 months in relation to those that observed the occurrence of violence in life.

According to the meta-analysis by Archer, the mutuality for physical violence seems to be important both for the dating phase and for cohabitation, diverging as to the magnitudes of the rates found, which are higher in the dating situation ${ }^{33}$. In the same tendency, the study by Straus points out to the difference of prevalence in dating, when compared to that of married partners living together: while the former have violence rate of $68 \%$, the latter presents a $50 \%$ rate $^{4}$.

The study by Stets and Straus refers that physical violence and other types of violence decrease fast with age. Results also show that reported values for women in physical violence are higher than for men, especially when they are younger ${ }^{36}$. These observations lead to the assumption that for women the rates of physical violence seem to decrease when changing from dating situations to cohabitation or marriage. In fact, if we contrast the rates found for female college students in São Paulo with women from São Paulo who are married, as in the study by Schraiber ${ }^{37}$, the magnitudes of the violence suffered by women who are married, even if high, are lower than the ones found in the dating situation. In these mentioned studies, mutuality was not found, and men were the main aggressors of the women in physical and sexual violence.

The same finding of the non-mutuality of violence is pointed out by $\mathrm{O}^{\prime}$ Leary $^{30}$ in the article in response to the meta-analysis by $\operatorname{Archer}^{33}$. He discusses about the limitation of generalizing the mutuality for distinct samples. In this same direction there are the studies by Laner and Thompson ${ }^{16}$, Billingham ${ }^{24}$ and $\mathrm{Chan}^{5}$, who consider the time of relationship, as well as the type of romantic involvement - dating or marriage - as factors that strongly influence the observed profile of 
violence. These studies point to "youth", in the sense of younger age groups as a factor associated to higher violence rates, as well as "time of relationship" measured by the "level of romantic involvement", as crucial factors to trigger violence during dating.

Even if violence during dating can be considered as a precursor of marital violence, reality is there are few studies that discuss the similarities and differences between the violence that takes place in a dating situation in contrast with the one occurring in marriage.

\section{Final Considerations}

The presented results enabled to know early information about the prevalence of two types of violence among college students in the dating relationship of a part of the Brazilian population. However, we cannot forget to recognize the missing information, limitations of a self-reported questionnaire, and the presence of incomplete questionnaires, which was corrected by data imputation. Another limiting aspect is the fact that it was answered only by one of the partners in the relationship, which can lead to information bias. We also remember that our data refer to two universities of São Paulo, even though the sample profile by gender and social stratification is the same found by the Higher Education Census produced by the Ministry of Education and Culture. First of all, it is worth to mention the importance of experiencing this type of violence at such early stages of human development and the expressive values of violence, especially the psychological and sexual types. It is urgent to analyze the process of changes verified in violence at the early dating phase until the marital relationship, in which determinations that consolidate violence caused by an intimate partner can be established.

This study is in accordance with the challenges presented in the study by Sears ${ }^{23}$, by pointing out the need of analyses studying that violence in dating increases the prevalence of violence in other forms that are not just physical, as well as the co-occurrence between the three types of violence, considered both from the perspective of the one who suffers and the one who perpetrates it. Besides, these authors show the lack of studies assessing the differences between men and women in the use of several forms of violence during dating or in specific combinations.

On the other hand, it is interesting to notice that this study included university students in their schools in their schools, by the convenience of the research viability, such as in many of the studies about violence during dating. Besides, it is in the context of schools that violent acts occur, according to the studied teenagers. This indicates that even when it comes to intimate partner violence, it commonly occurs in public and non-private or domestic environments, like between older married adults. As pointed out by Theriott ${ }^{7}$, those who experience some type of violence in the romantic relationship reported the occurrence of the fact in school spaces, in a proportion of 15 to $43 \%$, so the aggression can have been witnessed by a colleague or group of friends.

This aspect of violence between younger individuals, who bring the conflicts of intimacy to the school context and share them with colleagues and friends, on one hand reveals another specificity of this violence during dating, in contrast with the marital and cohabitation relationship, when the action is confined in the intimacy space. On the other hand, it clarifies the great opportunity that this characteristic allows to prevention programs.

Nonetheless, even by facilitating the existence of prevention programs, it is important to remember that high school or college students may not look for help for such matters, since literature shows that most of the time they do not recognize the acts as being violent. A set of actions that provide them with conditions to develop a posture of non-legitimation of violence in the romantic relationship, in the search of autonomy, still needs to be accomplished.

The findings in this study bring the confirmation of the need for actions and public policies in this direction, by producing important knowledge for prevention programs addressed to teenagers who are in the dating stage, in order to minimize the chances of aggressions during marriage. 


\section{References}

1. Barnett OW, Miller CLP, Perrin RD. Family violence across the life span. CA Thousand Oaks: Sage; 1997.

2. Heise L, Ellsberg M, Garcia-Moreno C. Intimate partner violence. In: Krug EG, Dahlberg LL, Mercy JÁ, Zwi AB, Lozano R (eds). World report on violence and health. Geneva: WHO; 2002. p. 91-121.

3. Gelles RJ, Straus MA. Intimate violence. New York: Simon \& Schuster, 1988.

4. Straus MA, Aldrighi T, Alvarez SD, Atan A, Boeckmann i, Sieber, C., et al. Prevalence of violence against dating partners by male and female university students worldwide. Violence Against Wom 2004; 10(7): 790-811.

5. Chan KL, Straus MA, Brownridge DA, Tiwari A, Leung WC. Prevalence of dating partner violence and suicidal ideation among male and female university students worldwide. J Midwifery Womens Health 2008; 53(6): 529-37.

6. Cardarelli AP. Violence between intimate partners: patterns, causes and effects. MA: Allyn and Bacon, 1997.

7. Theriot MT. Conceptual and Methodological Considerations for Assessment and Prevention of Adolescent Dating Violence and Stalking at School. Children \& Schools 2008; 30(4): 223-33.

8. Nascimento FS. Namoro e violência: um estudo sobre amor, namoro e violência para jovens de grupos populares e camadas médias [dissertação de mestrado]. Pernambuco: Universidade Federal de Pernambuco; 2009.

9. Njaine K, Assis SG, Oliveira QBM, Ribeiro FML, Avanci JQ. Violência nas relações afetivo-sexuais entre adolescentes da cidade de Manaus/AM. In: Meneghel SN (org). Rotas críticas II: ferramentas para trabalhar com a violência de gênero. Santa Cruz do Sul - SC: Edunisc; 2009 (1). p. 83-112

10. Aldrighi T. Prevalência e cronicidade da violência física no namoro entre jovens universitários do Estado de São Paulo Brasil. Psicol Teor Prat 2004; 6(1): 105-20.

11. Béjin A. O casamento extraconjugal dos dias de hoje. In: Ariès P e Béjin A (orgs.). Sexualidades ocidentais. São Paulo: Brasiliense. 1987; p. 183-93.

12. Straus MA. Cross-cultural reliability and validity of the Revised Conflict Tactics Scales: a study of university student dating couples in 17 nations. Cross Cultural Research 2004; 38(4): 407-32.

13. Hair-jr JF, Black WC, Babin BJ, Anderson RE, Tatham RL. Multivariate data Analysis. Nova Jersey: $6^{\mathrm{a}}$ edição. Pearson Prentice Hall; 2005. p. 49-76.

14. Shook NJ, Gerrity DA, Jurich J, Segrist AE. Courtship violence among college students: a comparison of verbally and physically abusive couples. J Fam Violence 2000; 15(1): 1-22.

15. Renner LM, Whitney SD. Examining symmetry in intimate partner violence among young adults using sociodemographic characteristics. J Fam Violence 2010; 25(2): 91-106.
16. Laner MR, Thompson J. Abuse and Aggression in Courting Couples. Deviant Behav 1982; 3: 229-44.

17. Mckinney K. Measures of verbal, physical, and sexual dating violence by gender. Free Inquiry in Creative Sociology 1986; 14: 55-60.

18. Machado C, Matos M, Moreira AI. Violência nas relações amorosas: Comportamentos e atitudes na população universitária. Psychologica 2003; 33: 69-83.

19. Paiva C, Figueiredo B. Abuso no relacionamento íntimo: Estudo de prevalência em jovens adultos portugueses. Psychologica 2004; 36: 75-107.

20. Scott K, Straus M. Denial, Minimization, Partner Blaming, and Intimate Aggression in Dating Partners. J Interpers Violence 2007; 22(7): 851-71.

21. Lysova AV. Dating violence in Russia. Russ Educ Soc 2007; 49(4): 43-59.

22. Hickman LA, Jaycox LH, Aronoff J. Dating violence among adolescents: Prevalence, gender distribution and prevention program effectiveness. Trauma Violence Abus 2004; 5(2): 123-42.

23. Sears HA, Byers ES, Price EL. The co-occurrence of adolescent boys'and girls' use of psychologically, psysically, and sexually abusive behaviours in their dating relationships. J Adolescence 2007; 30: 487-504.

24. Billingham RE. Courtship violence: The patterns of conflict resolution strategies across seven levels of emotional commitment. Fam Reat 1987; 36: 283-9.

25. Cornelius TL, Shorey RC, Kunde A. Legal consequences of dating violence: a critical review and directions for improved behavioral contingencies. Aggress Violent Beh 2009; 14: 194-204.

26. Mahoney P, Williams LM, West C. M. Violence against women by intimate relationships partners. In Rezenti, CM, Edleson JL, Bergen, RK (eds). Sourcerbook on violence against women. Thousand Oaks: Sage Publications, 2001. p. 143-78.

27. Hamby SL, Sugarman DB. Acts of psychological aggression against a partner and their relation to physical assault and gender. J Marriage Fam 1999; 61: 959-70.

28. Murphy CM, O'Leary KD. Psychological aggression predicts physical aggression in early marriage. J Consult Clin Psych 1989; 57: 579-82.

29. Jackson SM. Issues in the dating violence research: A review of the literature. Aggress Violent Beh 1999; 4(2): 233-47.

30. O'Leary DK. Are Women Really More Aggressive than Men in Intimate Relationships? Comment on Archer. Psychol Bull 2000; 136(5): 685-9.

31. Muñoz-Riva MJ, Graña JL, O’Leary KD, González MP. Prevalence and predictors of sexual aggression in dating relationships of adolescents and young adults. Psicothema 2009; 21(2): 234-40. 
32. Straus MA, Ramirez, I. L. Gender symmetry in prevalence, severity, and chronicity of physical aggression against dating partners by University students in Mexico and USA. In: XV World Meeting Of The International Society for Research on Aggression. Montreal, Canada. Durham, NH: University of New Hampshire, Family Research Laboratory; 2002.

Disponível em http://pubpages.unh.edu/ mas2/. Acesso (Acessado em 15 de março de 2008).

33. Archer J. Sex differences in aggression between heterosexual partners: A meta-analytic review. Psychol Bull 2000; 126: 651-80.

34. Dasgupta SA. Framework for understanding women's use of nonlethal violence in intimate heterosexual relationships. Violence Against Wom 2002; 8(11): 1364-89.
35. Kimmel MS. "Gender symmetry" in domestic violence: A substantive and methodological research review. Violence Against Wom 2002; 8(11): 1332-63.

36. Stets E, Straus MA. Gender differences in reporting marital violence and its medical and psychological consequences. In: Straus MA and Gelles RJ (eds.). Physical violence in American families: risk factors and adaptations to violence in 8,145 families. New Brunswick, NJ: Transaction Press; 1989. Chapter 9.

37. Schraiber LB, D'Oliveira AFPL, França JRI, Diniz S, Portella $\mathrm{AP}$, Ludemir AB, et al. Prevalência da violência contra a mulher por parceiro íntimo em regiões do Brasil. Rev Saúde Pública 2007; 41(5): 797-807.

Received on: $02 / 05 / 13$

Final version presented on: 04/18/13

Accepted on: 06/05/13 